\title{
THE AMERICAN SPIDERS OF THE GENERA STYPOSIS AND PHOLCOMMA (ARANEAE, THERIDIIDAE)*
}

\author{
By Herbert W. Levi \\ Museum of Comparative Zoology, Harvard University
}

Several new species have been discovered since publication only a few years ago of a paper on Styposis (Levi, 1960). One of these new species, $S$. selis, gives a clue to the relationship of the genus. The features characterizing Styposis are the ectally-facing embolus of the male palpus, and reduced or absent anterior median eyes. In only one other theridiid genus are there six-eyed species: Comaroma Bertkau, found in south-central Europe, Japan, and the western United States. However, the different structure of Comaroma genitalia and the large colulus suggest that the eye reduction evolved independently. The ectally-facing embolus is found also in one species of the genus Pholcomma ( $P$. hirsuta Emerton, Levi 1957), members of which also frequently have the anterior median eyes reduced in size, and the colulus replaced by two setae; but, unlike most species of Styposis, Pholcomma species usually have denticles on the posterior margin of of the chelicerae. In our revision of theridiid genera (Levi and Levi, 1962) it was suggested that there might be species intermediate between Styposis and Pholcomma. However the female of $S$. rancho here described has the epigynum similar to that of some Chilean Anelosimus species, a theridiid genus of larger spiders. But the epigynum of $S$. selis from southern Brazil resembles that of the Chilean Anelosimus, and furthermore the complexity of the male palpus also suggests that it belongs to the species group of Anelosimus endemic in Chile. The chelicerae have teeth on the posterior margin, as in Anelosimus and Pholcomma species, a feature uncommon in the Theridiidae. But unlike Chilean Anelosimus (Levi, 1936), S. selis has only six eyes. Before the discovery of $S$. selis, it was thought that the ectally facing embolus in some Chilean Anelosimus (Levi, I963), was a unique character, evolved independently. It is now evident that Styposis is intermediate between Pholcomma and the Chilean Anelosimus, the most abundant theridiid spiders in Chile, although Styposis generally lacks posterior teeth on the chelicerae. Styposis clausis has a rough cheliceral surface facing the fang and a carina ending in an indistinct tooth (Fig. IO).

Previously Styposis was known only from America; now a small

*Manuscript received by the editor December 3, 1963. 
specimen has been found in New Guinea, collected with a Berlese funnel in rain forest. The specimen is short-legged, pigmented and has eight eyes. It is the only Styposis specimen having habitat information.

The two species described here from South America are placed in Pholcomma tentatively, awaiting the discovery of males and additional specimens.

I would like to thank Dr. W. J. Gertsch of the American Museum of Natural History; Dr. A. Collart and J. Kekenbosch of the Institut Royal des Sciences Naturelles, Brussels; and Prof. M. Vachon of the Muséum National d'Histoire Naturelle, Paris (MNHN), for the loan of collections; and Prof. M. Birabén, director of the Museo Argentino de Ciencias Naturales, Buenos Aires, for the loan of a specimen from the La Plata Museum. This investigation was supported in part by Public Health Service Research Grant AI-or944, from the National Institute of Allergy and Infectious Diseases.

\section{Key to American Styposis species}

Ia. With six eyes (I96o, fig. I ; Fig. 8)

Ib. With eight eyes or six eyes and pigment spots in place of anterior medians ( 1960 , fig. 5, IO, I 8, 24)

\section{4}

2a. First patella-tibia less than one and one-half times carapace length; southern Brazil ................................... selis sp. n.

2b. First patella-tibia more than twice carapace length ……........ 3

3a. Male with first patella-tibia more than three times carapace length (Fig. I2); epigynum with a transverse knob (1960, fig. 3) ; Panama .............................................. clausis Levi

3b. Male with first patella-tibia two and one-half times carapace length; female unknown; Nicaragua ....... nicaraguensis Levi

4a. Abdomen wider than long ( 1960, fig. Io); Panama chickeringi Levi

4b. Abdomen larger than wide or subspherical ........................ 5

5a. Carapace sclerotized, with reticulate raised pattern ……....... 6

5b. Carapace lightly sclerotized, smooth ……...................... 7

6a. Carapace widest behind middle, rounded behind (I959, fig. I 8); Nicaragua to Venezuela flavescens Simon

6b. Carapace widest in middle, drawn out behind with a short stalk (1960, fig. 24) ; Panama ................................... scleropsis Levi

7a. Posterior median eyes separated by their diameter (1959, fig. 27) ; southwestern United States ............................ ajo Levi

7b. Posterior median eyes their radius or less apart .................. 8 


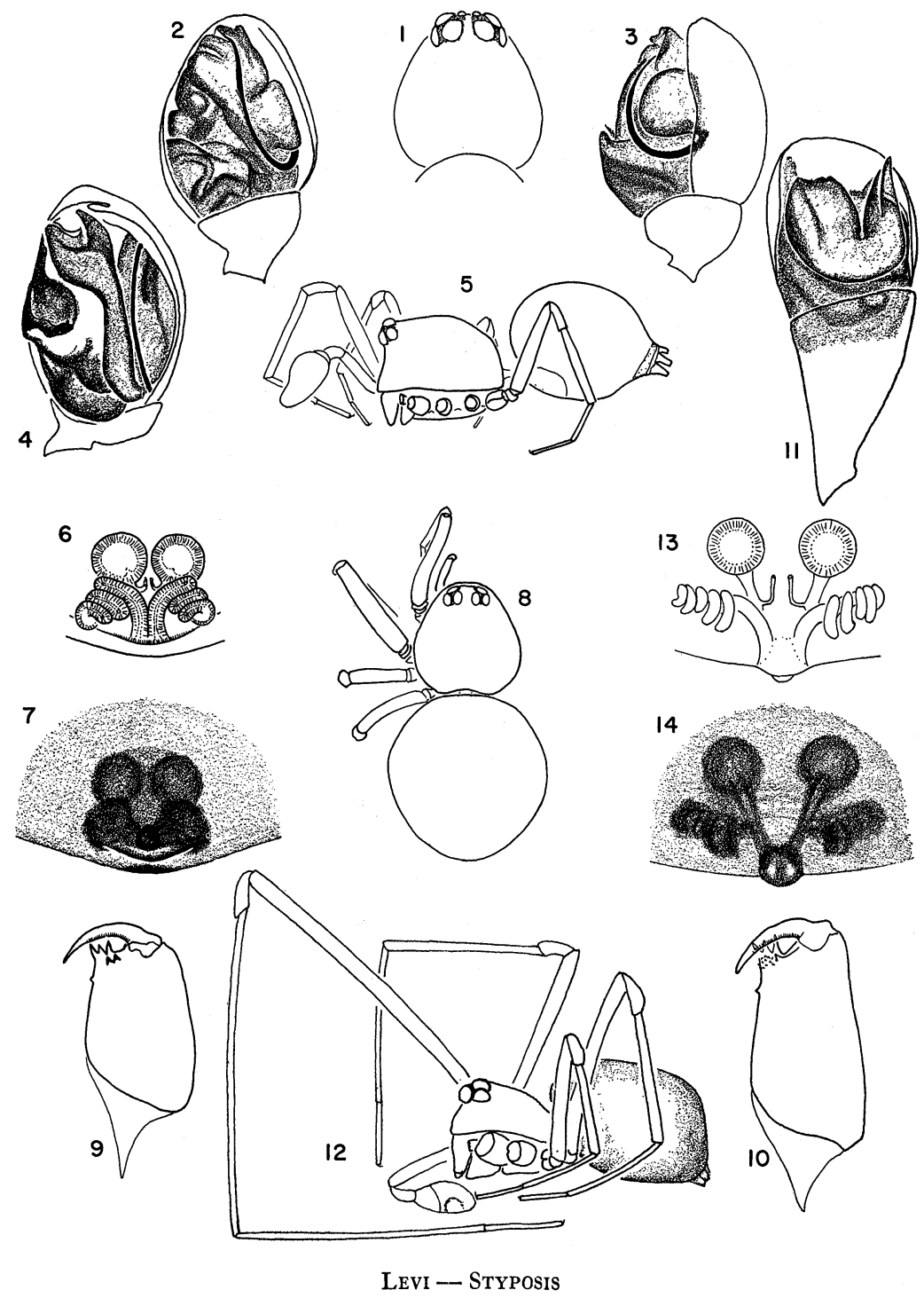


8a. Anterior lateral eyes separated by one diameter (1959, fig. 5); Venezuela rancho Levi

8b. Anterior lateral eyes separated by about one and one-half diameters (Fig. I) ; Equador colorados sp. n.

\section{Styposis colorados sp. n.}

Figures I-3

Holotype. Male from $35 \mathrm{~km}$ northwest of Santo Domingo de los Colorados, Pichincha, Ecuador, 22 Dec. 1958 (A. M. Nadler), in the American Museum of Natural History. The specific name is a noun in apposition after the type locality.

Description. Carapace, sternum, reddish brown. Legs grayish brown. Abdomen whitish. Diameter of anterior median eyes less than radius of other eyes. Anterior median eyes less than one diameter apart, touching laterals. Posterior median eyes their radius apart, almost touching laterals. Legs short. A small transverse, sclerotized plate anterior to spinnerets on venter. Between plate and spinnerets, two setae replace colulus. Total length I.O mm. Carapace 0.5 I $\mathrm{mm}$ long, $0.47 \mathrm{~mm}$ wide. First femur, $0.52 \mathrm{~mm}$; patella and tibia, $0.52 \mathrm{~mm}$; metatarsus, $0.39 \mathrm{~mm}$; tarsus, $0.25 \mathrm{~mm}$. Second patella and tibia, $0.4 \mathrm{I} \mathrm{mm}$; third, $0.35 \mathrm{~mm}$; fourth, $0.48 \mathrm{~mm}$.

Diagnosis. The embolus is on the ectal side of the palpus as in other Styposis (Figs. 2, 3), but is easily visible, and the species is thereby distinguished from $S$. rancho in which the embolus is difficult to see.

\section{Styposis selis sp. n.}

Figures 4-9

Holotype. Male from Nova Teutonia, lat $27^{\circ}$ i I'S, long $52^{\circ}$ 23'W, Santa Catarina, Brazil, July 1955 (F. Plaumann) in the Institut Royal des Sciences Naturelles, Brussels. The specific name is an arbitrary combination of letters.

Description. Carapace, sternum, legs yellow; abdomen whitish with

Explanation of Plate 5

Figs. 1-3. Styposis colorados sp. n. 1. Male Carapace. 2. Left palpus, ventral view. 3. Left palpus, ectal view.

Figs. 4-9. S. selis sp. n. 4. Palpus. 5. Male. 6. Female genitalia, dorsal view. 7. Epigynum. 8. Female. 9. Left female chelicera, posterior view.

Figs. 10-12. S. clausis Levi. 10. Left Female chelicera, posterior view. 11. Palpus. 12. Male.

Figs. 13-14. S. rancho Levi. 13. Female genitalia, dorsal view. 14. Epigynum. 
sclerotized part yellowish. Ducts and seminal receptacles black and showing through epigynum. Carapace of female longer than wide (Fig. 8), that of male almost circular and quite high (Fig. 5). Six eyes in two clumps touching each other. Posterior median eyes one diameter apart. Abdomen longer than wide. Abdomen of male with a lightly sclerotized ring around spinnerets. In female, first leg equals fourth in length; first leg longer than fourth in male. Total length of female $1.3 \mathrm{~mm}$. Carapace $0.55 \mathrm{~mm}$ long, $0.50 \mathrm{~mm}$ wide. First femur, $0.48 \mathrm{~mm}$; patella and tibia, $0.55 \mathrm{~mm}$; metatarsus, $0.26 \mathrm{~mm}$; tarsus $0.30 \mathrm{~mm}$. Second patella and tibia, $0.43 \mathrm{~mm}$; third $0.38 \mathrm{~mm}$. Fourth femur, $0.48 \mathrm{~mm}$; patella and tibia, $0.58 \mathrm{~mm}$; metatarsus, $0.26 \mathrm{~mm}$; tarsus, $0.31 \mathrm{~mm}$. Total length of male $1.2 \mathrm{~mm}$. Carapace $0.58 \mathrm{~mm}$ long, $0.54 \mathrm{~mm}$ wide. First femur, $0.54 \mathrm{~mm}$; patella and tibia, $0.64 \mathrm{~mm}$; metatarsus, $0.3 \mathrm{I} \mathrm{mm}$; tarsus, $0.32 \mathrm{~mm}$. Second patella and tibia, $0.47 \mathrm{~mm}$; third, $0.42 \mathrm{~mm}$; fourth, $0.60 \mathrm{~mm}$.

Diagnosis. The coiling of the heavily sclerotized ducts of the epigynum, and the Anelosimus-like palpus separate this species from $S$. clausis. The six eyes and small size separate the species from Chilean Anelosimus.

Records. 우 우, $0^{\star} 0^{\star}$ paratypes collected with holotype, July 1955 and August 1957 .

\section{Styposis rancho Levi}

Figures I3-I 4

Styposis rancho Levi, 1960, Psyche, 66; 18, figs. 5-6, ô. Male holotype from Rancho Grande, Venezuela, in the American Museum of Natural History.

Description of female. Coloration and eyes as in male. Abdomen subtriangular, as wide as long, widest anterior. Epigynum very transparent with dark ducts showing through (Fig. I4). The female has much longer legs than the male. Total length $1.6 \mathrm{~mm}$. Carapace $0.71 \mathrm{~mm}$ long, $0.66 \mathrm{~mm}$ wide. First femur, $1.72 \mathrm{~mm}$; patella and tibia, I. $80 \mathrm{~mm}$; metatarsus, I.30 $\mathrm{mm}$; tarsus, $0.52 \mathrm{~mm}$. Second patella and tibia, $1.30 \mathrm{~mm}$; third, $0.67 \mathrm{~mm}$; fourth, $1.03 \mathrm{~mm}$.

Records. Venezuela. Distrito Federal: Caracas, Dec. I887-Feb. I888, ㅇ (E. Simon, MNHN). A ragua: Tovar, Jan.-Feb. I888, $q$ (E. Simon, MNHN).

\section{Styposis clausis Levi}

Figures IO- 12

Styposis clausis Levi, 1960, Psyche, 66: 15, figs. 1, 2, 4, ㅇ. Female holotype from Forest Reserve, Panama Canal Zone, in the Museum of Comparative Zoology. 
Description of male. The animal is entirely yellow-white without pigment; abdomen whitish. Anterior lateral eyes more than one diameter apart. Posterior median eyes a little less than a diameter apart, touching laterals. Total length $1.7 \mathrm{~mm}$. Carapace $0.69 \mathrm{~mm}$ long, $0.69 \mathrm{~mm}$ wide. First femur, $1.97 \mathrm{~mm}$; patella and tibia, 2.22 $\mathrm{mm}$; metatarsus, $1.64 \mathrm{~mm}$; tarsus, $0.60 \mathrm{~mm}$. Second patella and tibia $1.72 \mathrm{~mm}$; third, $0.84 \mathrm{~mm}$; fourth I.I I $\mathrm{mm}$.

The male differs from the female by having a narrower abdomen. Records. Panama: El Valle, ㅇ, ơ, July 1936 (A. M. Chickering).

Key to American Pholcomma species

Ia. Carapace yellow-white ................................................. 2

ib. Carapace brown ......................................................... 3

2a. Male palpus with a spring-like coiled embolus (1957, figs. 3537) ; epigynum with anterior depression (1957, figs. 32-33); Pennsylvania to North Carolina .................... barnesi Levi

2b. Male palpus with a short embolus (1957, figs. 28-30) ; female unknown; North Carolina coast ............................ carota Levi

3a. Ducts anterior to seminal receptacles (I957, figs. 24-25); male palpus with embolus facing ectally ( 1957, figs. I9-2I) ; eastern United States to Wisconsin, Mississippi, Florida

hirsutum Emerton

3b. Ducts posterior of seminal receptacles; males unknown; South America

4a. Ducts, in ventral view, looping (Fig. I6) ; Catamarca, Argentina micropunctatum (Mello-Leitão)

4b. Ducts, in ventral view, straight (Fig. I8); Minas Gerais, Brazil mantinum sp. $\mathrm{n}$.

\section{Pholcomma hirsutum Emerton}

Pholcomma hirsutum Emerton, 1882, Trans. Connecticut Acad. Sci., 6:29, pl. 6, fig. 6, ㅇ, $\hat{o}$. Two female, one male syntypes from New Haven, Connecticut in the Museum of Comparative Zoology, examined. - Levi, 1957, Trans. Amer. Micros. Soc., 76:110, figs. 19-27, 48, map (hirsuta).

Note. The gender of the generic name is neuter.

\section{Pholcomma micropunctatum (Mello-Leitão)}

Figures I5-16

Dipoena micropunctata Mello-Leitao, 1941, Rev. Mus. La Plata, n. s., $2: 142$, fig. 37, . Female holotype from La Viña, Catamarca, Argentina in the Museo de La Plata, examined. 
15
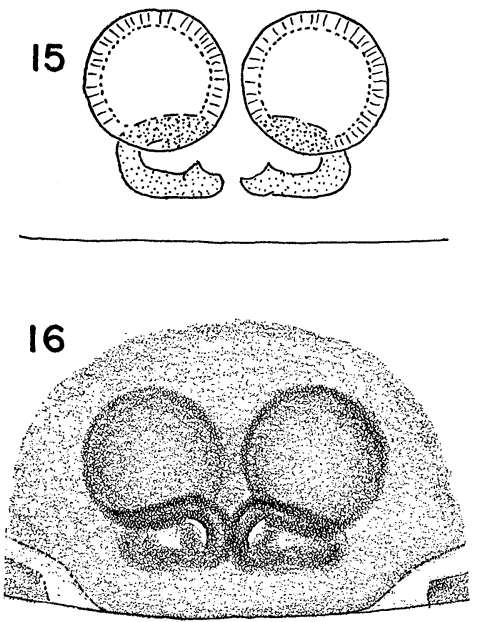

17
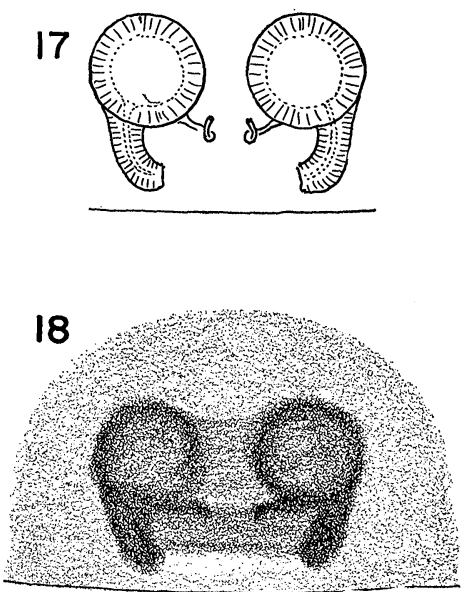

Figs. 15-16. "Pholcomma" micropunctatum (Mello-Leităo). 15. Epigynum cleared. 16. Epigynum.

Figs. 17-18. "Pholcomma" mantinum sp. n. 17. Epigynum cleared. 18. Epigynum.

Description. Sclerotized areas brown; abdomen gray with four white spots on anterior end of dorsum. Carapace, legs sclerotized. Carapace rather high. Eyes subequal in size. Anterior medians twothirds diameter apart, touching laterals. Posterior median eyes onethird diameter apart, one-quarter from laterals. Chelicerae weak, pointed on both ends, without teeth. Fang large, curved, almost onehalf total height of chelicerae. Abdomen with bases of setae sclerotized and some scattered small sclerotic spots. A sclerotic ring around pedicel and around spinnerets. Colulus with two setae. Total length $2.0 \mathrm{~mm}$. Carapace $0.7 \mathrm{I} \mathrm{mm} \mathrm{long.} \mathrm{First} \mathrm{patella} \mathrm{and} \mathrm{tibia} 0.93 \mathrm{~mm}$.

The male being unknown, placement of this species is uncertain. Since the female has only two seminal receptacles (Fig. I5) it cannot be a Dipoena and is probably not Euryopis. It differs from other Pholcomma by lacking teeth on the chelicerae. It is possible that the specimen lacks lungs and belongs to the family Symphytognathidae.

\section{Pholcomma mantinum sp. $\mathrm{n}$.} Figures I 7-I 8

Holotype. Female from Diamantina, Minas Gerais, Brazil in the American Museum of Natural History. The specific name is an arbitrary combination of letters. 
Description. The whole spider is brownish, the abdomen is lighter on venter. The carapace is sclerotized. The posterior median eyes are largest, the anterior median eyes smallest. The anterior median eyes are two-thirds their diameter apart, almost touching laterals. The posterior median eyes are almost touching, less than one-quarter diameter from laterals. The chelicerae are very small, the shape of an equilateral triangle, and lack teeth. The abdomen is suboval with setae coming from sclerotized round spots on dorsum. The sides seem folded and there is a sclerotized ring around the spinnerets. The colulus is replaced by two setae. Total length $\mathrm{I} .5 \mathrm{~mm}$. Carapace 0.62 $\mathrm{mm}$ long, $0.56 \mathrm{~mm}$ wide. Second patella and tibia $0.66 \mathrm{~mm}$; third $0.56 \mathrm{~mm}$. Fourth femur, $0.66 \mathrm{~mm}$, patella and tibia, $0.88 \mathrm{~mm}$.

The specimen is in poor physical condition.

Diagnosis. This specimen is quite close to $P$. micropunctatum (Mello-Leitão). The ducts of the genitalia are shorter (Figs. I7, I8). Along with $P$. micropunctatum this species may belong to the family Symphytognathidae; its placement in Pholcomma is tentative.

\section{References Cited}

LEVI, H. W.

1957. The North American Spider genera Paratheridula, Tekellina, Pholcomma and Archerius (Araneae, Theriidae). Trans. Amer. Micros. Soc., 76: 105-115.

1960. The spider genus Styposis (Araneae, Theridiidae). Psyche 66:1319.

1963. The American spiders of the genus Anelosimus (Araneae, Theridiidae). Trans. Amer. Micros. Soc., 82: 30-48.

Levi, H. W. and L. R. LeVI

1962. The genera of the spider family Theridiidae. Bull. Mus. Comp. Zool., 127 : 1-72. 

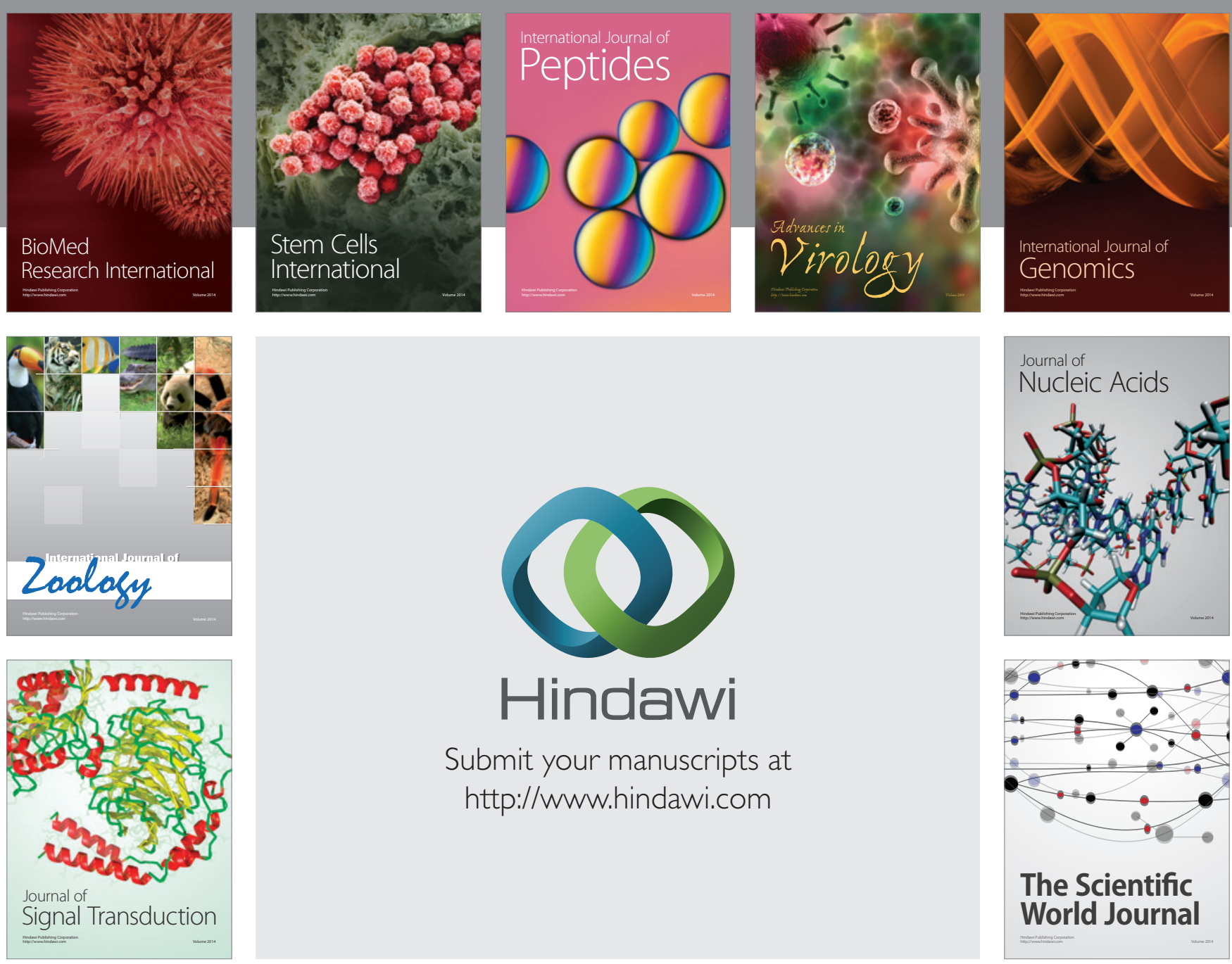

Submit your manuscripts at

http://www.hindawi.com
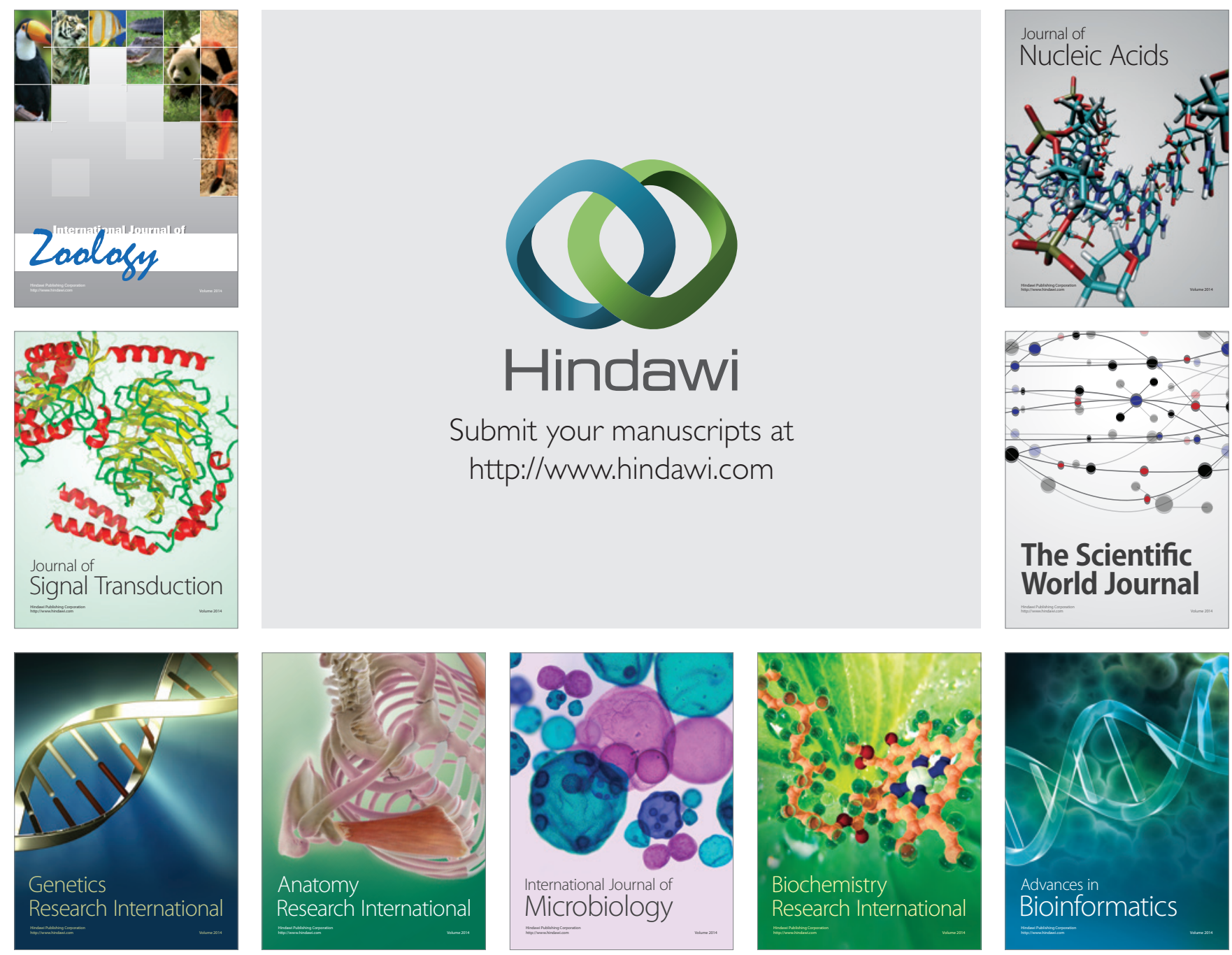

The Scientific World Journal
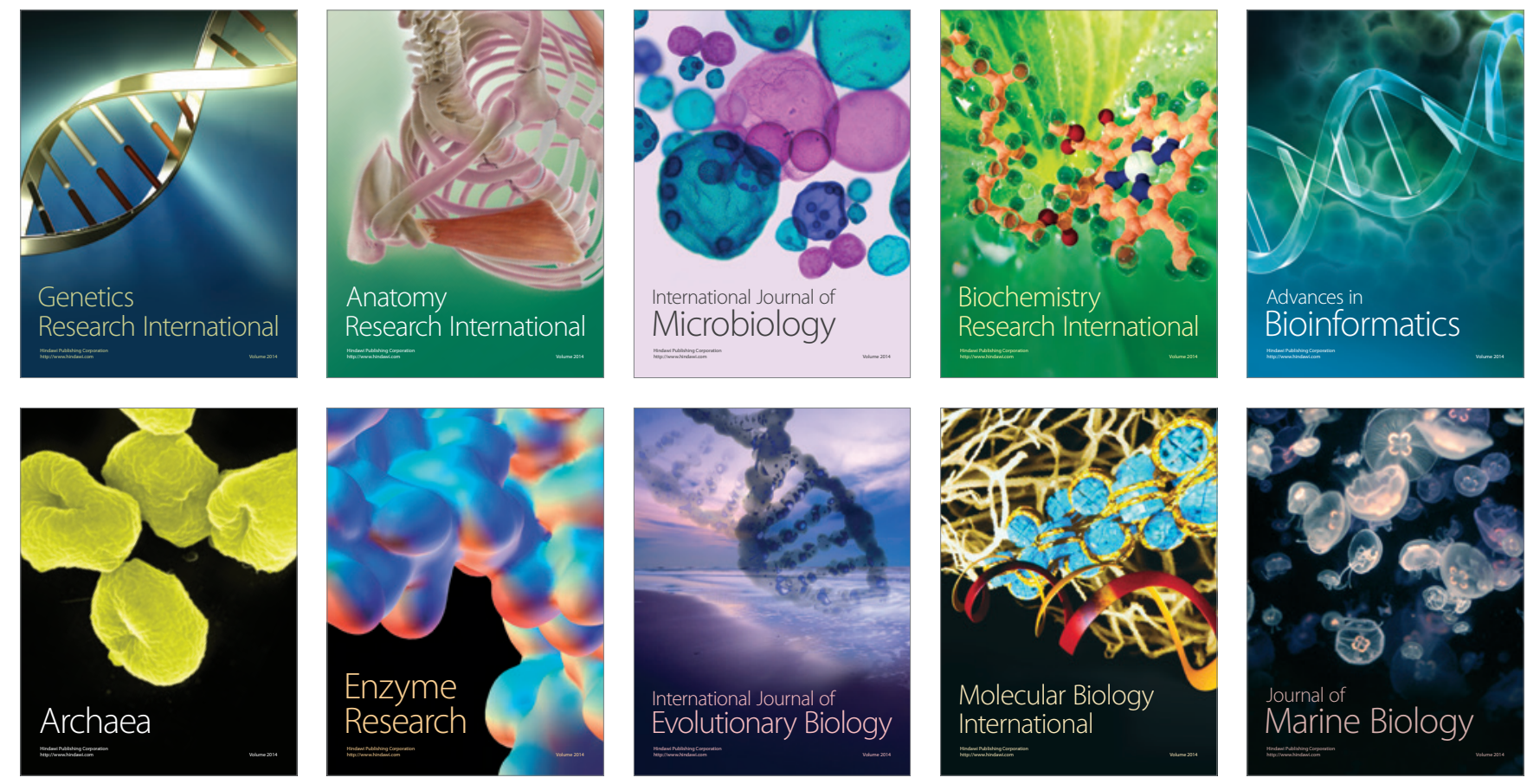